\title{
Demographic and Anthropometrical Analysis and Genotype Distribution of Chronic Hepatitis C Patients Treated in Public and Private Reference Centers in Brazil
}

Focaccia R. ${ }^{1}$, Baraldo D.C.M. ${ }^{1}$, Ferraz M.L.G. ${ }^{2}$, Martinelli A.L.C. ${ }^{3}$, Carrilho F.J. ${ }^{4}$, Gonçales Jr. F.L. 5 , Pedroso M.L.A. ${ }^{6,7}$, Coelho H.S.M. ${ }^{8,9}$, Lacerda M.A. ${ }^{10}$, Brandão C.E. ${ }^{11}$,Mattos A.A. ${ }^{12,13}$, Lira L.G.C. ${ }^{14,15}$, Zamin Jr. I. ${ }^{13}$, Pinheiro J.O.P. ${ }^{13}$, Tovo C.V. ${ }^{12,13}$ Both C.T. ${ }^{13}$, Soares J.A.S. ${ }^{8,9}$ and Dittrich S. ${ }^{13}$

\begin{abstract}
Emílio Ribas Institute ${ }^{1}$, São Paulo/SP; Federal University of São Paulon, São Paulo/SP; Medical School of Ribeirão Preto (São Paulo University) ${ }^{3}$, Ribeirão Preto/SP; School of Medicine of São Paulo University ${ }^{4}$, São Paulo/SP; Medical Sciences Faculty of the University of Campinas ${ }^{5}$, Campinas/SP; Federal University of Paraná ${ }^{\text {, Curitiba/PR; CRE Metropolitan }}$ (Secretary of State of Paraná) ${ }^{7}$, Curitiba/PR; Federal University of Rio de Janeiro ${ }^{8}$, Rio de Janeiro/RJ; Private Institution ${ }^{9}$, Rio de Janeiro/RJ; Private Institution ${ }^{10}$, Curitiba/PR; Graffée Guinle Universitary Hospital (UNIRIO) ${ }^{11}$, Rio de Janeiro/RJ; Gastroenterology Service of Santa Casa de Misericórdia ${ }^{12}$, Porto Alegre/RS; Private Institution ${ }^{13}$, Porto Alegre/RS; Federal University of Bahia ${ }^{14}$, Salvador/BA; Private Institution ${ }^{15}$, Salvador/BA, Brazil
\end{abstract}

\begin{abstract}
Hepatitis $\mathrm{C}$ virus $(\mathrm{HCV})$ infection is a serious public health problem, since $80 \%$ to $85 \%$ of HCV carriers develop a persistent infection that can progress into liver cirrhosis and hepatocarcinoma. Considering that the response of hepatitis $\mathrm{C}$ patients to combination therapy with interferon and ribavirin depends on $\mathrm{HCV}$ characteristics as well as on host features, we made a retrospective analysis of demographic and anthropometrical data and $\mathrm{HCV}$ genotype distribution of chronic hepatitis $\mathbf{C}$ patients treated in public and private reference centers in Brazil. The medical records of 4,996 patients were reviewed, $81 \%$ from public and $19 \%$ from private institutions. Patients' median age was 46 years, and there was a higher prevalence of male $(62 \%)$ and white patients $(80 \%)$. The analysis of $\mathrm{HCV}$-infecting strains showed a predominance of genotype $1(64 \%)$ over genotypes 2 and 3. The patients' mean weight was $70.6 \mathrm{~kg}$, and $65 \%$ of the patients weighed less than $77 \mathrm{~kg}$. Overweight and obesity were observed in $37.8 \%$ and $13.6 \%$ of the patients, respectively. Since a body weight of $75 \mathrm{~kg}$ or less has been considered an independent factor that significantly increases the odds of achieving a sustained virological response, the Brazilian population seems to have a more favorable body weight profile to achieve a sustained response than the American and European populations. The finding that $65 \%$ of chronic hepatitis C patients have a body weight of $77 \mathrm{~kg}$ or less may have a positive pharmacoeconomic impact on the treatment of genotype $1 \mathrm{HCV}$ patients with weight-based doses of peginterferon.

Key Words: HCV, chronic hepatitis C, genotype, body weight, Brazil.
\end{abstract}

Received on 17 March 2004; revised 15 July 2004.

Address for correspondence: Dr. Roberto Focaccia. Instituto de Infectologia Emílio Ribas. Diretoria Científica. Av. Dr.Arnaldo, 165. São Paulo, SP, Brazil, Zip code: 01246-900. Phone:(+11)3896-1241. Fax:(+11)3826-4688.

E-mail:focaccia@uol.com.br

The Brazilian Journal of Infectious Diseases 2004;8(5):348-355 (C) 2004 by The Brazilian Journal of Infectious Diseases and Contexto Publishing. All rights reserved.
Hepatitis C virus (HCV) was identified in 1989 [1]; it is responsible for about $90 \%$ of the so-called non-A non-B hepatitis. It is a RNA virus of the Flaviviridae (Flavivirus) family and Hepacivirus gender [2] that is primarily transmitted through infected blood [3].

HCV infection affects about 170 million people worldwide and is currently one of the major public health problems in Brazil and in the world [4]. According to 
the Brazilian Hepatology Society, local epidemiological information is still incipient. Brazilian studies on this subject have been predominantly aimed at risk groups (drug addicts [5], patients undergoing hemodialysis [6] and blood donors [7-12]). So far, only a few investigators have addressed the prevalence of hepatitis $\mathrm{C}$ in the general population $[13,14]$.

Focaccia et al. [13] made a populational, randomized and stratified study, and reported a prevalence of $1.42 \%$ of HCV carriers in the city of São Paulo, with rates increasing with age, reaching over $3.5 \%$ in individuals aged 30 years and over. In spite of HCV's low infectivity and slow replication rate, $80 \%$ to $85 \%$ of the patients will develop a persistent, asymptomatic (or oligosymptomatic) infection that may progress into liver cirrhosis in approximately $20 \%$ of the patients and into hepatocellular carcinoma in part of these cases [15,16].

Considering that the response of $\mathrm{HCV}$ patients to combination therapy with interferon and ribavirin depends on intrinsic HCV characteristics, such as genotype, as well as on host features such as sex, age, the degree of liver fibrosis [17] and body weight [18], we made a retrospective analysis of demographic and anthropometrical data and of HCV genotype distribution of chronic hepatitis $\mathrm{C}$ patients treated in public and private reference centers in Brazil.

\section{Material and Methods}

A retrospective analysis was made of the medical records of $\mathrm{HCV}$ carriers older than 14 years followed up in 11 reference public institutions and four specialized private hospitals. Medical records of HCV patients treated within the two years preceding the study were sequentially included; $74 \%$ of the hepatitis $\mathrm{C}$ diagnoses were made after 1998. One or more health professionals designated by the principal investigator reviewed the medical records and transferred selected data into a "Data Collection Form".

The following data were collected: number of the medical record, patient's initials, age, sex, color, weight, height, HCV genotype and origin (geographic area, private versus public institution) and entered in a computerized database that generated a report with descriptive statistics for all variables. After data collection, a second review was performed for a sample of $10 \%$ of the records by comparatively checking the information in the data collection forms and the respective source documents for quality assurance of the collection process. The $\chi^{2}$ test was used for statistical analysis and significant differences were considered when $\mathrm{p}<0.05$.

\section{Results}

\section{Demographic data}

The medical records of 4,996 patients were reviewed, and 4,041 (81\%) were from public and 955 (19\%) from private institutions. Most data were collected in the southeast region of the country (69\%), $27 \%$ in the south region and $4 \%$ in the northeast region. The patients were 15 to 98 years old, with a median age of 46 years, 50 years for females (16 - 87 years) and 44 years for males (15 - 98 years). Only $0.5 \%$ of the patients were 14 to 19 years old, $27.5 \%$ were 20 to 39 years old, $58 \%$ were 40 to 59 years old and $14 \%$ were 60 years or older. Sixty two percent were males and $38 \%$ were females. Eighty percent of the patients were white (Table 1).

\section{HCV genotype}

Information on the HCV genotype was available for only $27 \%$ of the medical records. The following distribution was observed: $64 \%$ for genotype $1,3 \%$ for genotype 2 and $33 \%$ for genotype 3 . The highest prevalence of genotype 3 was observed in the south region (Figure 1).

\section{Anthropometrical data}

Information on patients' weight was available for $72 \%$ of the medical records. The patients mean weight was $70.6 \mathrm{~kg}$, and it was significantly higher in males 
Table 1. Demographic data of 4,996 Brazilian chronic hepatitis C patients

\begin{tabular}{lc}
\hline Characteristics & Values \\
\hline Gender & \\
Male & $61.5 \%$ \\
Female & $37.8 \%$ \\
Color & \\
$\quad$ White & $80 \%$ \\
Nonwhite & $20 \%$ \\
Age (Median, Range) & 46 yrs $(15-98$ yrs $)$ \\
Female & 50 yrs $(16-87$ yrs $)$ \\
Male & 44 yrs $(15-98$ yrs $)$ \\
Age distribution & \\
$14-19$ yrs & $0.5 \%$ \\
$20-39$ yrs & $27.5 \%$ \\
$40-59$ yrs & $58.0 \%$ \\
$>60$ yrs & $14.0 \%$ \\
\hline
\end{tabular}

Figure 1. Genotype distribution of hepatitis $\mathrm{C}$ virus in the three Brazilian geographic regions.

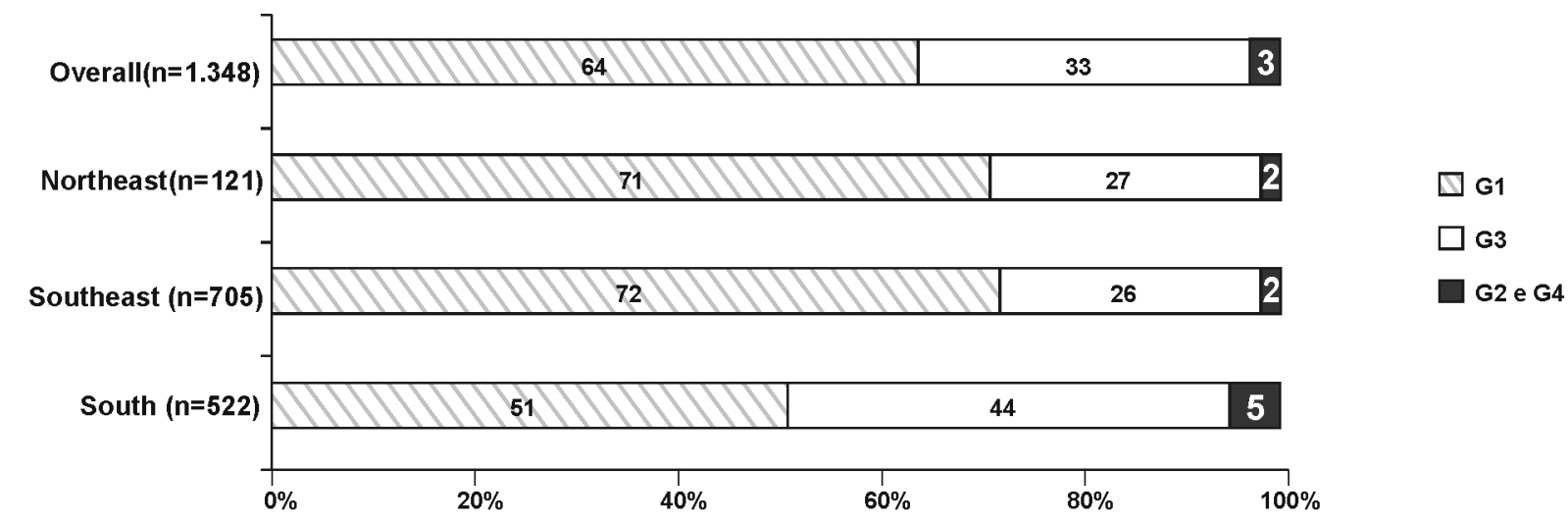


than in females (76.7 $\mathrm{kg}$ versus $64.9 \mathrm{~kg}$, respectively) $(\mathrm{p}<0.0001)$. Most patients $(65 \%)$ weighed less than $77 \mathrm{~kg}$ (Figure 2). No significant differences were observed between weight distributions among the three regions of the country (Figure 3) or between patients followed in public and private institutions (Figure 4).

Height data was available for $30.7 \%$ of the medical records, making it possible to calculate body mass index (BMI) for these patients. BMI was normal in 47.9\% of the patients, whereas overweight and obesity were observed in $37.8 \%$ and $13.6 \%$ of the patients, respectively (Table 2 ).

\section{Discussion}

It is well known that intrinsic $\mathrm{HCV}$ characteristics can influence the rates of sustained virological response (SVR) to interferon-based therapy; however, host features may also interfere with response to treatment $[17,18]$. Though retrospective studies might be inaccurate because of the way data are retrieved rather than how they are recorded, they are often the only source of information, especially in countries like Brazil, where prospective populational studies are not always feasible.

The median age of 46 years for the chronic hepatitis $\mathrm{C}$ patients in this study was very close to that reported in other Brazilian surveys by Bassit et al. (mean age of 47 years) [19] and by Medeiros-Filho et al. (mean age of 49.7 years). Similarly to the Medeiros-Filho's sample, most of the patients who were followed-up were 40 to 60 years old (60 and 58\%, respectively) [20].

As reported by Bassit et al. [19], there was a higher prevalence of males (62\%). Other publications have already shown this prevalence, reporting rates ranging from $64 \%$ to $72 \%$ [21-24]. This result probably reflects the characteristics of the blood donor population, constituted of presumably healthy adult males who seek medical assistance after being diagnosed in blood banks. In addition, it is known that drug abuse and sexual behaviors that predispose to sexually transmittable disease are more common among males [25].
Although HCV genotype determines the duration of the combination therapy with interferon- $\alpha$ and ribavirin, HCV genotyping was carried out in only $27 \%$ of the patients under treatment. The distribution of $\mathrm{HCV}$ infecting strains was similar to that previously reported in other studies [19,26], with prevalence of genotype $1(64 \%)$ over genotypes 2 and 3 . The regional genotype distribution also confirmed the higher prevalence of genotype 3 in the south region reported by Campiotto et al. [26].

The scarcity of Brazilian anthropometrical data makes the interpretation of weight and BMI data in chronic HCV patients difficult. The percentage of obese and overweight patients was $51.4 \%$ in our sample, whereas a survey carried out in 1997 in southeast and northeast Brazil found an overweight and obesity prevalence of $38.5 \%$ [27]. The increased prevalence of overweight and obese patients observed in our study compared to that of 1997 might be due to regional differences; however, taking into consideration the influence of obesity associated with liver steatosis on the response to the combination therapy [28], further studies are required to clarify this issue.

Analysis of the results of phase III clinical trials with interferon $\alpha$-2b have shown that SVR rates are greatly influenced by body weight, since smaller body weights were associated with higher sustained response rates [29]. The impact of body weight on SVR was also reported by a PEG IFN $\alpha$-2a monotherapy study [30] as well as by a PEG IFN $\alpha$-2a plus ribavirin study, where three factors were shown to independently and significantly increase the odds of achieving a SVR: a non $-1 \mathrm{HCV}$ genotype, age $=40$ years and body weight $=75 \mathrm{~kg}$ [18].

This is the first clinical study to evaluate the weight of chronic hepatitis $\mathrm{C}$ patients in Brazil. The mean weight of $70.6 \mathrm{~kg}$ observed in this survey suggests that the Brazilian population has a more favorable body weight profile to achieve a SVR than the American and European populations, whose mean weight has ranged from $73 \mathrm{~kg}$ to $82 \mathrm{~kg}[17,18,31,32]$ in previous studies with ribavirin and interferon or peginterferon. We also found that $65 \%$ of the chronic hepatitis $\mathrm{C}$ patients had a body weight of $77 \mathrm{~kg}$ or less. This finding may have 
Figure 2. Distribution of chronic hepatitis $\mathrm{C}$ patients according to body weight.

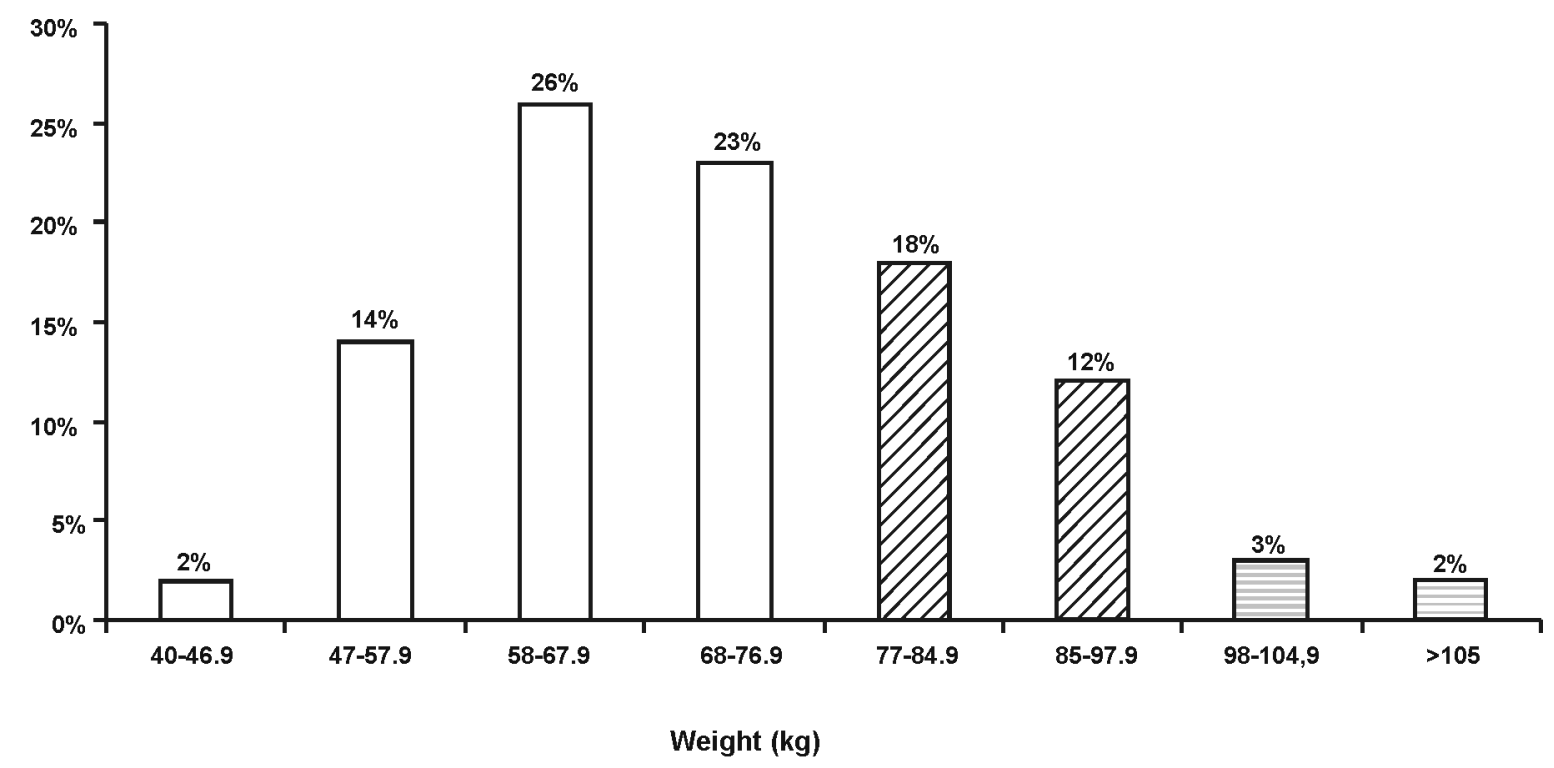

Figure 3. Weight distribution of chronic hepatitis $\mathrm{C}$ patients according to geographic region.

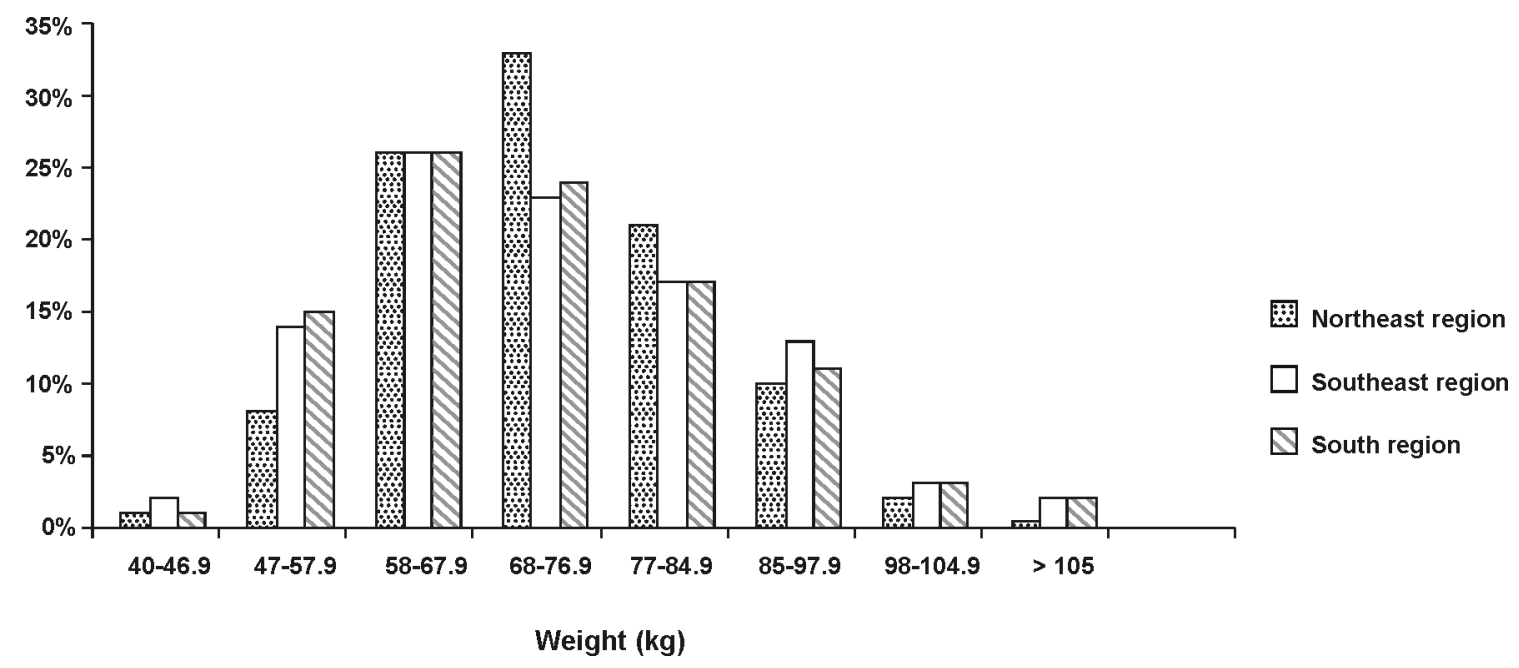


Figure 4. Weight distribution of chronic hepatitis $\mathrm{C}$ patients according to reference center (public or private).

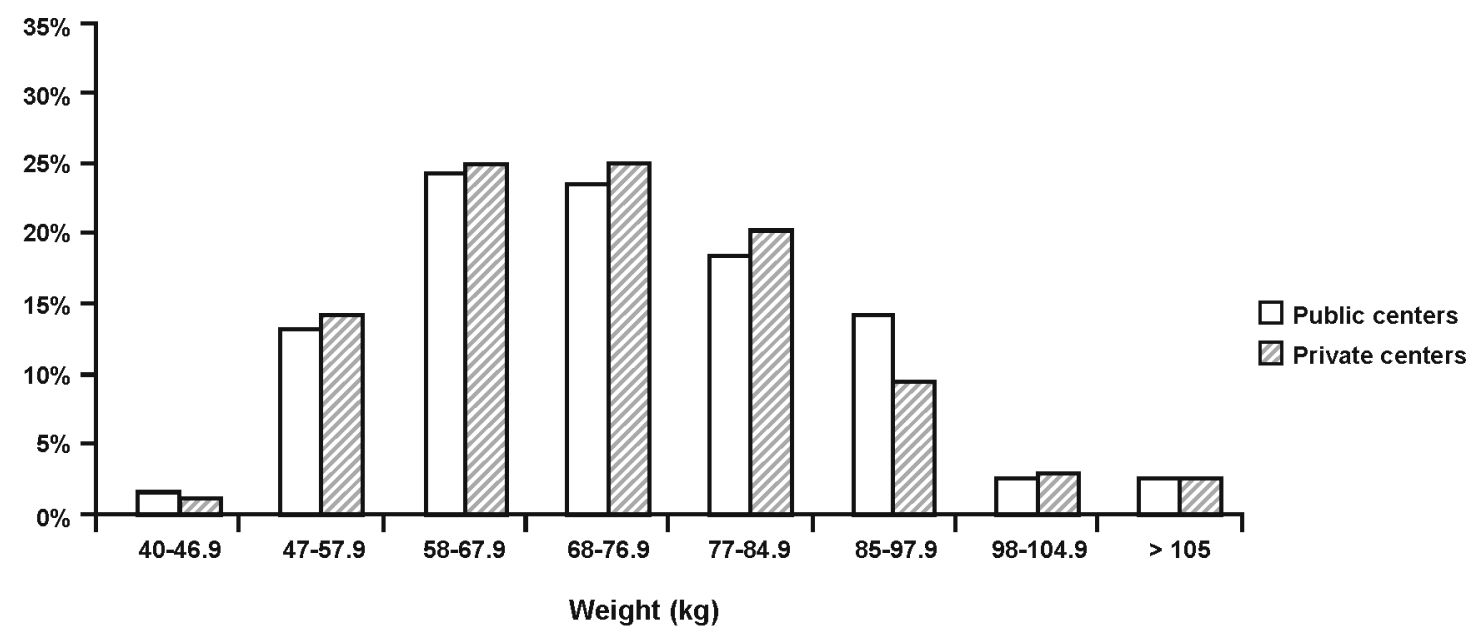

Table 2. Body Mass Index of 1,533 Brazilian chronic hepatitis $\mathrm{C}$ patients

\begin{tabular}{ll}
\hline Body mass index & \% \\
\hline$<25$ (normal) & 47.9 \\
$25-29.9$ (overweight) & 37.8 \\
$30-40$ (obesity) & 13.6 \\
$>40$ (morbid obesity) & 0.7 \\
\hline
\end{tabular}

a positive pharmacoeconomic impact on the treatment of patients infected by genotype 1 with weight-based dosing of peginterferon. The inclusion of an economic perspective has become an increasingly accepted component to establish health care policies and planning [33], and knowing the population's characteristics may be useful when allocating scarce public health resources.

Therefore, it is essential that governmental strategies are developed to allow a better understanding of the $\mathrm{HCV}$ population and hence optimize resources in this important public health care problem.

\section{Acknowledgements}

Financial support was provided by Indústria Química e Farmacêutica Schering-Plough S. A.

\section{References}

1. Choo Q.L., Kuo G., Weiner A.J., et al. Isolation of a cDNA clone derived from a blood-borne non-A, non-B viral hepatitis genome. Science 1989;244(4902):359-62.

2. Purcell R. The hepatitis $\mathrm{C}$ virus: overview. Hepatology 1997;26(3 suppl 1):11S-4S. 
3. Focaccia R., Baraldo D.C.M., Souza F.V. Hepatite C. Epidemiologia. In: Tratado de Hepatites virais. Focaccia R. São Paulo: Atheneu, 2003: 221-9.

4. Report of a WHO Consultation organized in collaboration with the Viral Hepatitis Prevention Board, Antwerp, Belgium. Global surveillance and control of hepatitis $C$. J Viral Hepat 1999; 6:35- 47.

5. Oliveira M.L., Bastos F.I., Telles P.R., et al. Prevalence and risk factors for HBV, and HDV infections among injecting drug users from Rio de Janeiro, Brazil. Braz J Med Biol Res 1999;32(9):1007-14.

6. Yoshida C.F., Takahashi C., Gaspar A.M., et al. Hepatitis $\mathrm{C}$ virus in chronic hemodialysis patients with non- $\mathrm{A}$ non-B hepatitis. Nefron 1992;60:150-3.

7. Parolin M.B., Russo A.A., de Almeida P.T., et al. Multicenter study on the prevalence of hepatitis $C$ virus infection in blood donors in the city of Curitiba, Brazil. Arq Gastroenterol 1999;36(3):117-21.

8. Patino-Sarcinelli F., Hyman J., Camacho L.A., et al. Prevalence and risk factors for hepatitis $\mathrm{C}$ antibodies in volunteer blood donors in Brazil. Transfusion 1994;34(2):138-41.

9. Vanderborgth B.O., Reis A.M., Rouzere C.D., et al. Prevalence of anti-hepatitis $\mathrm{C}$ vírus in the blood donor population of Rio de Janeiro. Vox Sang 1993; 65(2): 122-5.

10. Gonçales Jr F.L., Boccato R.S.B.S., Pedro R.J. et al. Prevalências do HBsAg, do anti-HBc e do anti-HCV na população de candidatos a doadores de sangue do Hemocentro-Campinas. Rev Inst Med Trop São Paulo 1993;35(1):45-51.

11. Gonçales Jr F.L., Pedro R.J., Silva L.J., et al. Hepatites pós-transfusionais na cidade de Campinas, SP, Brasil. I - Incidência, agentes etiológicos e aspectos clínicosepidemiológicos da hepatite por vírus C. Rev Inst Med Trop São Paulo 1993;35(1):53-63.

12. Gonçales Jr F.L., Pedro R.J., Silva L.J., et al. Hepatites pós-transfusionais na cidade de Campinas, SP, Brasil. II - Presença dos anticorpos anti-HBc e anti-HCV em candidatos a doadores de sangue e ocorrência de hepatites pós-transfusionais pelo virus C nos receptores de sangue ou derivados. Rev Inst Med Trop São Paulo 1993;35(1):63-71.

13. Focaccia R., Conceição O.J., Sette-Jr H., et al. Estimated prevalence of viral hepatitis on the general population of the municipality of Sao Paulo, measured by plasmatic markers through samples collected from stratified, randomized and residence-based population survey. Braz J Infect Dis 1998;2:269-84.

14. Silva L., Parana R., Mota E., et al. Prevalence of hepatitis $\mathrm{C}$ virus in urban and rural populations of northeast Brazil - pilot study. Arq Gastroenterol 1995;32(4):168-71.
15. Seef L.B., Buskell-Bales Z., Wright Z., et al. Long-term mortality after transfusion- associated non-A. non-B hepatitis. New Eng J Med 1992;327:1906-11.

16. Takahashi M., Yamada G., Miyamoto R., et al. Natural course of chronic hepatitis C. Am J Gastroenterol 1993,88:240-3.

17. Poynard T., Marcellin P., Lee S.S., et al. Randomised trial of interferon alpha2b plus ribavirin for 48 weeks or for 24 weeks versus interferon alpha $2 \mathrm{~b}$ plus placebo for 48 weeks for treatment of chronic infection with hepatitis $\mathrm{C}$ virus. International Hepatitis Interventional Therapy Group (IHIT). Lancet 1998;352(9138):1426-32.

18. Fried M.W., Shiffman M.L., Reddy K.R., et al. Peginterferon alfa-2a plus ribavirin for chronic hepatitis C virus infection. N Engl J Med 2002;347(13):975-82.

19. Bassit L., Da Silva L.C., Ribeiro-dos-Santos G., et al. Chronic hepatitis $\mathrm{C}$ virus in Brazilian patients: association with genotypes, clinical parameters and response to long term alpha interferon therapy. Rev Inst Med Trop Sao Paulo 1999;41(3):183-9.

20. Medeiros-Filho J.E., Gardia B.D., Nita S.K., et al. Aspectos epidemiológicos da infecção crônica pelo VHC no HCFMUSP - São Paulo: Experiência de 628 casos. GED Gastrenterologia e Endoscopia Digestiva 2001;20(1):S40.

21. Merican I., Sherlock S., McIntyre N., et al. Clinical, biochemical and histological features in 102 patients with chronic hepatitis C virus infection. Q J Med 1993;86:119-25.

22. Delladetsima J.K., Rassidakis G., Tassopoulos N.C., et al. Histopathology of chronic hepatitis $\mathrm{C}$ in relation to epidemiological factors. J Hepatol 1996;24:27-32.

23. Van Thiel D.H., Friedlander L., Malloy P., et al. Gamaglutamyl transpeptidase as a response predictor when using alfa-interferon to treat hepatitis C. Hepatogastroenterology 1995;42(6):888-92.

24. Graf J., Torivama K., Itakura H. A clinic-pathological study of 163 untreated cases of chronic hepatitis C. Rev Soc Bras Med Trop 1996;29(1):21-5.

25. Conry-Cantilena C., VanRaden M., Gibble J., et al. Routes of infection, viremia, and liver disease in blood donors found to have hepatitis $\mathrm{C}$ virus infection. $\mathrm{N}$ Engl J Med 1996;334(26):1691-6.

26. Campiotto S., Pinho J.R., Silva L.C., et al. Distribuição dos genótipos do vírus da hepatite $\mathrm{C}$ nas diferentes regiões do Brasil. Dados preliminares. GED -Gastrenterologia e Endoscopia Digestiva 1998; 17 :S64.

27. Monteiro C.A., Conde W.L. A tendência secular da obesidade segundo estratos sociais: nordeste e sudeste do Brasil, 1975-1989-1997. Arq Bras Endoc Metab 1999;43:186-94.

28. Poynard T., Ratziu V., McHutchison J., et al. Effect of treatment with peginterferon or interferon alfa- $2 b$ and ribavirin on steatosis in patients infected with hepatitis C. Hepatology 2003;38(1):75-85. 
29. McHutchison J.G., Poynard T., Salpetriere P., et al. Patient body weight and response to interferon alfa $2 \mathrm{~b}$ monotherapy [abstract no. 998]. In: 52 ${ }^{\text {nd }}$ Annual Meeting of the American Association for the Study of Liver Diseases (AASLD); 2001 Nov 9-13; Dallas, Texas. Hepatology 2001;34(4 Pt 2):407A.

30. Zeuzem S., Feinman V., Rasenack J., et al. Peginterferon alfa-2a in patients with chronic hepatitis C. N Engl J Med 2000;343(23):1666-72.

31. McHutchison J.G., Gordon S.C., Schiff E.R., et al. Interferon alfa-2b alone or in combination with ribavirin as initial treatment for chronic hepatitis C. Hepatitis Interventional Therapy Group. N Engl J Med 1998;339(21):1485-92.

32. Manns M.P., McHutchison J.G., Gordon S.C., et al. PegInterferon alfa-2b plus ribavirin compared with interferon alfa-2b plus ribavirin for initial treatment of chronic hepatitis $\mathrm{C}$ : a randomised trial. Lancet 2001;358(9286):958-65.

33. Hutubessy R., Chisholm D., Edejer T.T. Generalized costeffectiveness analysis for national-level priority -setting in the health sector. Cost Eff Resour Alloc 2003;1:8. 